"Chinese Girl Wants Vote":

The Asian-American Suffragette Mabel Ping-Hua Lee

\title{
Grace Li
}


The battle for suffrage in New York State spanned for sixty-nine years before most women were granted the right to vote on November $8,1917 .{ }^{1}$ Many activists were instrumental in the success of this campaign, including Dr. Mabel Ping Hua Lee, a long-time advocate for social reform and the first Chinese woman to receive a doctoral degree from Columbia University. I say “most women,” because although Lee participated in the fight for women’s suffrage, she did not receive this right in November 1917: under the terms of the Chinese Exclusion Act of 1882, she and all other Chinese men and women were barred from voting until the act's dissolution in $1943 .^{2}$ The Act temporarily curtailed Chinese immigration and attempted to make life more difficult for Chinese people in America through institutional means, as the U.S. government enacted a series of discriminatory policies at local and federal levels, ranging from limitations on Chinese employment opportunities to official mandates for their removal from the country. ${ }^{3}$ Within this political context, historians such as Yue Xiao agree that Lee's decision to parade on horseback in a feminist demonstration in New York, at only sixteen years old, was all the more pointed. ${ }^{4}$ This article will argue that Lee’s dedication to social activism and support for the women's suffrage movement grew from greater contextual influences, including the backdrop of the Chinese Exclusion Act of 1882 and Lee’s upbringing in New York, a state with a particularly active women’s suffrage movement; and various personal factors, including Lee’s family, education, and religiosity. ${ }^{5}$

\footnotetext{
${ }^{1}$ Susan Goodier and Karen Pastorello Women Will Vote: Winning Suffrage In New York State, (Ithaca: Three Hills, an imprint of Cornell University Press, 2017), 183.

${ }^{2}$ Estelle T. Lau, Paper Families: Identity, Immigration Administration, and Chinese Exclusion, (Duke University Press, 2006), 15.

3ibid., 13.

${ }^{4}$ Yue Xiao, "Chinese Economic Development and Chinese Women Economists", in The Routledge Handbook of the History of Women's Economic Thought, ed. Kirsten Madden and Robert W. Dimand, (Abingdon: Routledge, 2018): 293.

${ }^{5}$ I would like to emphasize that this research is particularly important in recognizing the contributions of traditionally marginalized voices in American women's suffrage history. I hope that through this article, I will be able to play my part in challenging mainstream understandings and trends in women's suffrage history and historical academia as a whole.
} 


\section{Chinese Exclusion}

The Chinese were the first group of immigrants the United States government "actively sought to keep out of the country;” however, as author John Soennichsen observes, the origins of select restrictive immigration policies provided only a small window into "larger networks and structures" that perpetuated the exclusion of Chinese people from the American narrative. ${ }^{6}$ The Act to Execute Certain Treaty Stipulations Relating to Chinese was enacted in 1882, following decades of festering anti-Chinese animosity between the 1850s and 1880s. These sentiments were manifested in public acts of physical and verbal harassment against Chinese people, destruction of their property, and a series of ordinances dubbed “nuisance laws," designed to disrupt the daily lives of Chinese Americans. ${ }^{7}$ The official Chinese Exclusion Act of 1882 prohibited “further immigration to the United States by Chinese laborers,” required ChineseAmericans living in the U.S. to register with the federal government and carry valid passports at all times, and declared all Chinese-Americans ineligible for U.S. citizenship. ${ }^{8}$ The exclusion of Chinese Americans from American citizenship legislated the exclusion of Chinese voices from American political life altogether, which accompanied the physical exclusion of Chinese immigrants from the United States. The phenomenon of Chinese resistance, however, "pushed U.S. law to develop” and is integral to the Chinese-American narrative. ${ }^{9}$

Chinese Americans “[subverted] and [manipulated] the regulatory system” in response to the discriminatory policies put forth by the U.S. government. ${ }^{10}$ To illustrate this, attorney and scholar Estelle T. Lau explores how Chinese-Americans constructed 'paper families' as a form

\footnotetext{
${ }^{6}$ Lau, 1; John Soennichsen, “The Chinese Exclusion Act of 1882,” Pacific Northwesterner (2012): 16-17.

${ }^{7}$ Soennichsen, 16-17.

${ }^{8}$ Ibid.,18.

${ }^{9}$ Lau, 2.

${ }^{10}$ Ibid.
} 
of resistance against anti-Chinese immigration laws. Stemming from a loophole in U.S. immigration law which "granted children of U.S. citizens, regardless of place of birth, eligibility for U.S. citizenship, and thus, immigration,” U.S. citizens of Chinese descent created fictive or 'paper families' by extending kinship status to Chinese people seeking entry who would otherwise be denied entry. ${ }^{11}$ The U.S. immigration bureau responded to these tactics by exercising "heightened discretion in their handling of immigration processing," and developed an "increasingly bureaucratic structure to implement a highly-detailed interrogation procedure."12 This example of resistance to the ongoing policies of ethnic discrimination during the period of the "Chinese Question" shaped the way that Chinese people grew to understand their identities and communities within America. Themes of resistance and resilience not only empowered Chinese-American communities and identity but were woven into their very foundations. As a Chinese-American woman who grew up in this period, Mabel Lee was undoubtedly influenced by these practices.

Although Chinese Americans could not vote at the time, Lee's participation in the New York suffrage parade in 1917 was of huge symbolic importance both to women and to the Chinese community. ${ }^{13}$ The first thought I had when I read about Lee was: what could compel a teenage girl to march with a movement that would not benefit her or anyone of her ethnicity? I presume this is a question many would have asked themselves as they read the striking title "Chinese Girl Wants Vote," dictated alongside a large black-and-white portrait of Lee on the

\footnotetext{
${ }^{11}$ Lau., 5.

12 These reforms worked somewhat counterproductively, given that immigration inspectors could not verify the responses given by prospective Chinese immigrants due to their limited understanding of Chinese language, customs, and way of life, forcing inspectors to strictly rely on the administrative procedure in processing claims for entry; Ibid., 5-6.

13 “Dr. Mabel Ping-Hua Lee,” National Parks Service, U.S. Department of the Interior, April 19, 2019, https://www.nps.gov/people/mabel-lee.htm.
} 
pages of the New York Tribune on April 13, 1912. ${ }^{14}$ Lee’s being featured in the Tribune propelled her to the forefront of a growing social movement, which not only brought another vibrant dimension to the women's suffrage movement but encouraged discourse on the "Chinese question,” as journalism was the primary method of reaching the masses at the time. Lee's appearance at the parade and subsequent publication represented the intersection of two marginalized groups: Chinese Americans and American women. Her refusal to remain silent on the issue of women's suffrage simultaneously served as a political statement that Chinese Americans refused to be silenced into submission and were active members of political and civil society.

\section{From Guangzhou to New York}

Mabel Ping Hua Lee was born in Guangzhou, China in 1897, and immigrated to New York with her mother, before being reunited with her father at four years old, where she was educated in the city's public schools. ${ }^{15}$ Her father was the pastor of the Baptist Chinese Mission in New York’s Chinatown, where the family settled. The Gold Rush attracted many early Chinese immigrants to California and the Pacific Northwest, where they would congregate in areas of exclusive Asian population known as “Chinatowns.” ${ }^{16}$ Western ordinances which indicated anti-Chinese hostility, however, pushed Chinese immigrants eastward, towards Boston, Chicago, and New

\footnotetext{
14 “Chinese Girl Wants Vote,” New York Tribune, (New York, NY), April 13, 1912; Dr. Mabel Ping-Hua Lee. ${ }^{15}$ Xiao, 293; Timothy Tseng, “Asian American Legacy: Dr. Mabel Lee,” last modified December 12, 2013, https://timtseng.net/2013/12/12/asian-american-legacy-dr-mabel-lee/.

${ }^{16}$ Soennichsen, 6; Chinatowns are defined as "a type of ethnic town formed by ethnic Chinese," where Chinese people "reside and maintain economic, social, and cultural facilities." Chinatowns only exist outside of China, where Chinese culture is exposed to and subsequently adapt to a host society's mainstream culture. Thus, while Chinatowns all generally serve economic and associational purposes, Chinatowns in different regions of the world often feature different regionally contextualized characteristics; Kiyomi Yamashita, “A Comparative Study of Chinatowns around the World: Focusing on the Increase in New Chinese Immigrants and Formation of New Chinatowns,” Japanese Journal of Human Geography 65, no. 6 (2013): 528.
} 
York. ${ }^{17}$ Asian American historian Mary Ting Yi Lui describes how early literature on New York Chinatowns painted them as "impenetrable enclaves or colonies" of people intrinsically unable to be Americanized. ${ }^{18}$ The physical and cultural isolation of this exclusionary rhetoric forced Chinese Americans to look inwards to their communities for support through shared experience, and Chinatown was the cultural hub necessary for Chinese Americans to secure a sense of collective identity. Lee’s upbringing in a space that reinforced her cultural identity likely shaped how she perceived her identity as one worth standing up for.

Throughout her life, Lee demonstrated pride in her Chinese culture and devoted her life to the betterment of the Chinese and Chinese-American communities. While studying at Barnard College, Lee contributed feminist essays to The Chinese Students' Monthly and promoted girls’ education and civic participation within the Chinese community. ${ }^{19}$ Later in her life, she also founded the Chinese Christian Center, a community center in New York City that offered vocational and English classes, health services, and kindergarten. Therefore, we may observe that Lee’s activism and desire for social reform were not limited to suffrage but were rooted in a genuine desire to serve and improve her community. Lee's Chinese heritage and her womanhood were both central to her identity; so, while suffrage may not have extended to her at the time, Lee's support of the women's suffrage movement represented a desire to advance a cause that would better the lives of many American women, a community that was also an intrinsic part of her identity.

\footnotetext{
${ }^{17}$ Tracy Steffes, “Chinese,” Encyclopedia of Chicago, accessed November 26, 2019, http://www.encyclopedia.chicagohistory.org/pages/285.html.

${ }^{18}$ Mary Ting Yi Lui, "Examining New Trends in Chinese American Urban Community Studies," Journal of Urban History 29: no. 2 (2003): 174.

${ }^{19}$ Dr. Mabel Ping-Hua Lee.
} 
The women in Lee’s community also supported her activism. In 1917, Lee mobilized a group of women in her local Chinese community to march with her in a women's suffrage parade. ${ }^{20}$ By encouraging women from her cultural community to follow her lead, Lee bridged two intrinsic parts of her identity: her Chinese culture with her gender. The women who marched with Lee would also not benefit from the legalization of women's suffrage; nonetheless, they saw value in supporting the movement. Both women and Chinese Americans have experienced policies of discrimination, and Lee felt connected to the marginalization of both groups.

\section{Women's Suffrage in New York}

The suffrage movement in New York had its roots in American revolutionary rhetoric, was "nurtured through the antebellum period and abolition,” and survived the course of westward expansion, the Civil War, and Reconstruction. ${ }^{21}$ By exploring explore the decades of rich history which shaped and supported the movement in New York prior to 1917, we can gain a deeper understanding of the significance of the New York women’s suffrage movement. ${ }^{22}$

As feminist intellectual historian Linda Kerber argues, the archetype of the model republican woman, birthed from the chaos of the American Revolution, as a mother and wife brought women into closer proximity with political systems. ${ }^{23}$ The ideology of Republican Motherhood, although nuanced, presented the progressive notion that women could and should play a political role by "influencing their husbands and raising patriotic children.” ${ }^{24}$ Although the extent of their direct participation in the political process was limited by social and legal codes,

\footnotetext{
${ }^{20}$ Carl Samson, "Meet the First Chinese American Woman to Fight for Voting Rights That History Almost Forgot," NextShark (blog), November 6, 2019, https://nextshark.com/mabel-lee-womens-suffrage-pioneer//.

${ }^{21}$ Goodier and Pastorello, 2.

22 Ibid.

${ }^{23}$ Linda K. Kerber, "Why Diamonds Really Are a Girl's Best Friend: The Republican Mother and the Woman Citizen,” Women's America, 8th, ed. Linda K. Kerber, Jane Sherron De Hart, Cornelia Hughes Dayton, and Karissa Haugeberg, (New York, New York: Oxford University Press, 2016), 122.

${ }^{24}$ Kerber, 122.
} 
this post-revolutionary rhetoric proposed that women could be political creatures by "redefining female political behaviour as valuable rather than abnormal,” and a source of strength for the republic. ${ }^{25}$ This idea would serve as a foundational precedent to the women's suffrage movement.

In the mid-19th century, discontent with the way American law defined gender relations grew. Elizabeth Cady Stanton, Lucretia Mott, Martha Coffin Wright, Jane Hunt, and Mary Ann M’Clintock were the five suffragists from upstate New York who spearheaded the 1848 Declaration of Sentiments—a document based on the Declaration of Independence, meant to air the grievances of women and their passionate desire for legal personhood. ${ }^{26}$ The Declaration was presented at a women’s rights convention in Seneca Falls, New York on July 19th and 20th, 1848, which drew a crowd of about 300 people to debate its merits. ${ }^{27}$ One of the most controversial resolutions proposed at the convention was the assertion that the duty of the government was to secure the "sacred right to...elective franchise” for American women. ${ }^{28}$ Gerda Lerner, a scholar in American women’s history, regards the Seneca Falls Woman’s Rights Convention as the beginning of the women's rights movement, as the Declaration of Sentiments would become a landmark resolution for decades of women's rights reforms in New York and the greater United States. ${ }^{29}$ New York has been described by American women’s history scholar

\footnotetext{
${ }^{25}$ Despite this cultural progress, Republican Motherhood flourished within the context of coverture - the old law of domestic relations which did not legally recognize wives as their own persons within a marriage. This limited the extent to which women could be political, and what purpose their political participation would serve. Women were to "contain their political judgements within their homes and families" - therefore, as Kerber describes, the Republican wife "was a citizen, but not really a constituent”; Kerber, 123.

${ }^{26}$ Gerda Lerner, “The Meaning of Seneca Falls,” In Women's America, $8^{\text {th }}$, ed. Linda K. Kerber, Jane Sherron De Hart, Cornelia Hughes Dayton, and Karissa Haugeberg (New York, New York: Oxford University Press, 2016), 223.

${ }^{27}$ Goodier and Pastorello, 8-9; Lerner 222.

${ }^{28}$ Elizabeth Cady Stanton, Susan B Anthony, and Matilda Joslyn Gage, "Declaration of Sentiments,” Women's America, ${ }^{\text {th }}$, ed. Linda K. Kerber, Jane Sherron De Hart, Cornelia Hughes Dayton, and Karissa Haugeberg, (New York, New York: Oxford University Press, 2016), 249.

${ }^{29}$ Lerner, 222; Goodier and Pastorello, 9.
} 
Susan Goodier and women and gender studies scholar Karen Pastello as having "led the United States politically, economically, and culturally,” and after Seneca Falls, annual women’s rights conventions would be held most often in New York State. ${ }^{30}$ Further, New York was notably the first state east of the Mississippi River to recognize women’s right to suffrage through a public referendum, indicating that the majority of voting New Yorkers supported the decision to enfranchise women. ${ }^{31}$ The prominent role of New York State in the development of the greater American women's suffrage movement would shape the future of the movement within New York itself.

The New York women's suffrage movement experienced a unique vibrancy largely due to their opportunities to gain notoriety through the popular media. New York was home to six daily newspapers which supported the dissemination of suffrage materials to the public; numerous suffrage organizations; and a large, actively engaged audience for the suffrage movement. ${ }^{32}$ For example, the aforementioned article about Lee, “Chinese Girl Wants Vote,” was published in the New York Tribune, founded by Horace Greeley. In his book Horace Greeley and the Politics of Reform in Nineteenth-Century America, Mitchell Snay-a historian specializing in American civilization—speaks to how Greeley employed and befriended early leading feminists, and was noted to have seemingly “[valued]...reform-minded women” and “lent a sympathetic ear to the women’s movement."33 This likely framed the trajectory of the stories covered by the paper, and the Tribune grew to become a significant paper in the United States at the time due to its inexpensiveness, which appealed to the average reader. The paper's

\footnotetext{
${ }^{30}$ Goodier and Pastorello, 2, 10.

31 Ibid., 2.

32 Ibid.

${ }_{33}$ Mitchell Snay, Horace Greeley and the Politics of Reform in Nineteenth-Century America (Lanham, Md.: Rowman \& Littlefield Publishers, Inc., 2011): 72.
} 
popularity, coupled with the other New York print media outlets, helped to bring the ideals of the suffrage movement to mainstream audiences, as newspapers were the primary source of news for everyday people. ${ }^{34}$ Lee was fluent in English and, living in New York, would have had access to and been able to read and engage with such material in the Tribune and other New York papers. This exposure to progressive politics and more specifically women’s suffrage materials likely shaped Lee’s positive perception of women’s suffrage and social activism.

\section{"The Meaning of Woman Suffrage"}

In addition to geographic and cultural factors, Lee’s religious beliefs, family background, and education were important influences on her suffrage activism. Lee’s perspective on women’s suffrage is illuminated in an article she wrote for The Chinese Student Monthly in 1914 while attending Barnard College, entitled “The Meaning of Woman Suffrage.”35 This article demonstrates how Lee’s faith influenced her understanding of democracy to include universal suffrage. Lee believed that the fundamental principle of democracy was equality of opportunity and saw suffrage for women as the “application of democracy to women.” ${ }^{36}$ Lee was deeply religious and would go on to take over for her father as director of the First Chinese Baptist Church. Theological scholar Grace May describes how Lee saw an intrinsic connection between democracy and Christianity and derived a spiritual understanding of equality from Christ’s statement that "slaves had as much as princes in the sight of God." 37 The feminist movement provided Lee with an opportunity to advocate for the "equality of opportunity for women to

\footnotetext{
34 “About New-York Tribune,” Library of Congress, accessed November 18, 2019, https://chroniclingamerica.loc.gov/lccn/sn83030214/.

${ }_{35}$ Dr. Mabel Ping-Hua Lee.; Barnard College was an all-women’s college founded because Columbia University refused to admit women.

${ }^{36}$ Mabel Lee, “The Meaning of Woman Suffrage,” The Chinese Students Monthly 9, no. 7 (May 12, 1914): 526, https://archive.org/details/chinesestudentsm14bost/page/508.

${ }^{37}$ Grace May, “Leading Development at Home: Dr. Mabel Ping Hua Lee (1896-1966),” William Carey International Development Journal: Women in International Development, (November 1, 2016), https://www.wciujournal.org/journal/article/leading-development-at-home-dr.-mabel-ping-hua-lee-1896-1966.
} 
prove their merits.” ${ }^{38}$ In "The Meaning of Woman Suffrage,” she describes four stages of feminist development in a democracy: the spiritual, legal, political, and economic. ${ }^{39}$ Lee recognizes the spiritual stage, tied to the early Christian movement, as the first and foundational stage of her beliefs—but also emphasizes the political stage, pertaining to the question of extending political rights to women, as the "most immediately pressing demand." ${ }^{\prime 0}$ This theory of democratic feminist development reflects how Lee understood and conceptualized feminism and women's suffrage through the lens of her faith, which provided a spiritual underpinning for her advocacy.

Lee’s family background was also formative for her activism, as her parents showed public support for suffrage during her youth. Her father's progressive evangelical religious vision nurtured her suffragist convictions, and her mother, despite her ties to traditional Chinese feminity as represented by her bound feet, also quietly participated in the movement. ${ }^{41}$ Although the Tribune, in its article about Lee, attempted to paint her mother as traditional and backwardthinking and credited Mabel's paternal influences for her "strong mind and...admiration for American institutions,” it is important to recognize that both Lee's parents supported women's suffrage. This support allowed her to pursue channels of social activism without fear of dishonouring her parents—an especially important consideration in Chinese culture. Lee’s father was particularly proud to invest in his daughter's education. ${ }^{42}$

Lee was an active member of the Debate Club and wrote numerous articles for the Chinese Students’ Association during her time at Barnard College, which she attended as the

\footnotetext{
${ }^{38}$ Lee, The Meaning, 527.

${ }^{39}$ Ibid.

${ }^{40}$ Ibid., 529; Lee mentions the "early Christian movement" in her piece but does not explicitly state which specific movement she is referring to.

${ }^{41}$ May.

${ }^{42}$ Chinese Girl, 3.
} 
first woman to receive the Boxer Indemnity Scholarship, which supported the education of Chinese students in American colleges and universities. ${ }^{43}$ She dedicated herself to her studies immediately, and saw education as a means to empower women by proving their intellectual capability. ${ }^{44}$ In particular, in a speech entitled "China’s Submerged Half” which she delivered at a suffrage shop run by the Women's Political Union in 1915, Lee argued that literate women were considered unattractive because it threatened the status quo of the western world. ${ }^{45}$ In this speech, she used her platform to urge the Chinese community to encourage girls' education and women's civic participation. ${ }^{46}$ Lee saw education as a means of opening the door "to [a] treasury of knowledge”; she recognized that when Chinese women were deprived of an education, they were "walled in" from experiencing life like their male counterparts. ${ }^{47}$ Mabel proposed that the education of Chinese girls in American institutions would be a marked sign of positive change in the U.S., freeing women from archaic social customs. ${ }^{48}$ Lee evidently believed that her education served not only as a channel of personal empowerment, but was integral to her understanding of feminism and the empowerment of women in general, particularly Chinese-American women like Lee herself.

\footnotetext{
${ }^{43}$ Samson; May; “The Boxer Indemnity Scholarship Program,” China Comes to MIT, accessed November 26, 2019, http://chinacomestomit.org/new-page-2.

${ }^{44}$ May.

${ }^{45}$ Dr. Mabel Ping-Hua Lee.; Suffrage shops were semi-public retail spaces which represented the commercialization of women's suffrage through the merchandising of women's suffrage literature and commodities; John Mercer, "Shopping for Suffrage: the Campaign Shops of the Women's Social and Political Union," Womens History Review 18, no. 2 (April 2, 2009): 293-294.

${ }^{46}$ Mabel Ping-Hua Lee, “China’s Submerged Half” (Speech, New York, NY, 1915), https://timtsengdotnet.files.wordpress.com/2013/12/mabel-lee-speech-china_s-submerged.pdf; The transcript of this speech I have is a copy that Dr. Timothy Tseng found at the New York Chinese Baptist Church, and since I do not have the original, I cannot be certain of the accuracy of the transcript.

${ }^{47}$ Mabel Ping-Hua Lee, “China’s Submerged Half” (Speech, New York, NY, 1915), https://timtsengdotnet.files.wordpress.com/2013/12/mabel-lee-speech-china_s-submerged.pdf. ${ }^{48}$ Ibid.
} 


\section{Conclusion}

Unlike the women mentioned above-Stanton, Mott, Wright, Hunt, and M’Clintock—Mabel Ping-Hua Lee is not taught in many history books and is unlikely to come to mind when the American women's suffrage movement is mentioned. However, her passionate activism undoubtedly broke barriers for Chinese Americans and American women. The political context of the Chinese Exclusion Act of 1882 in the United States and New York, the New York women’s suffrage movement, and aspects of Mabel’s personal life, including her family, education, and religiosity, were integral parts of her life experience which shaped her into a social reformer and an advocate for the women's suffrage movement. Her story is one of selflessness and resilience in the face of racial and gender discrimination. Telling and re-telling stories like Lee's is important because they bring to light the narratives that have been suppressed and neglected throughout American history. One of the greatest ways that historians can attempt to rectify the injustices of the past is by expanding the scholarship on these marginalized narratives. 
Bibliography

Primary Sources

“Chinese Girl Wants Vote.” New York Tribune, April 13, 1912. https://chroniclingamerica.loc.gov/lccn/sn83030214/1912-04-13/ed-1/seq-3/.

Lee, Mabel Ping-Hua. "The Meaning of Woman Suffrage.” The Chinese Students Monthly 9, no. 7 (May 12, 1914): 526-31. https://archive.org/details/chinesestudentsm14bost/page/508.

Lee, Mabel Ping-Hua. “China’s Submerged Half.” Speech, New York, NY, 1915. Accessed November 26, 2019. https://timtsengdotnet.files.wordpress.com/2013/12/mabel-leespeech-china_s-submerged.pdf.

Stanton, Elizabeth Cady, Susan B Anthony, and Matilda Joslyn Gage. "Declaration of Sentiments." In Women's America, $8^{\text {th }}$ ed.: 247-50. New York, New York: Oxford University Press, 2016.

\section{Secondary Sources}

“About New-York Tribune.” Library of Congress. Library of Congress. Accessed November 18, 2019. https://chroniclingamerica.loc.gov/lccn/sn83030214/.

“Dr. Mabel Ping-Hua Lee.” National Parks Service. U.S. Department of the Interior, April 19, 2019. Accessed November 18, 2019. https://www.nps.gov/people/mabel-lee.htm.

Goodier, Susan, and Karen Pastorello. Women Will Vote: Winning Suffrage in New York State. Ithaca: Three Hills, an imprint of Cornell University Press, 2017.

Kerber, Linda K. "Why Diamonds Really Are a Girl's Best Friend: The Republican Mother and the Woman Citizen.” In Women's America, edited by Linda K. Kerber, Jane Sherron De Hart, Cornelia Hughes Dayton, and Karissa Haugeberg, $8^{\text {th }}: 117-25$. New York, New York: Oxford University Press, 2016.

Lau, Estelle T. Paper Families: Identity, Immigration Administration, and Chinese Exclusion. Durham: Duke University Press, 2006.

Lerner, Gerda. “The Meaning of Seneca Falls.” In Women's America, edited by Linda K. Kerber, Jane Sherron De Hart, Cornelia Hughes Dayton, and Karissa Haugeberg, 8th: 221-27. New York, New York: Oxford University Press, 2016.

Lui, Mary Ting Yi. 2003. "Examining New Trends in Chinese American Urban Community Studies.” Journal of Urban History 29 (2): 174. Accessed November 18, 2019. https://doi.org/10.1177/0096144202238873.

May, Grace. “Leading Development at Home: Dr. Mabel Ping Hua Lee (1896-1966).” William Carey International Development Journal: Women in International Development 
(November 1, 2016). Accessed November 18, 2019.

https://www.wciujournal.org/journal/article/leading-development-at-home-dr.-mabelping-hua-lee-1896-1966.

Mercer, John. "Shopping for Suffrage: the Campaign Shops of the Women's Social and Political Union.” Womens History Review 18, no. 2 (April 2, 2009): 293-309. Accessed November 26, 2019. https://doi.org/10.1080/09612020902771053.

Samson, Carl. "Meet the First Chinese American Woman to Fight for Voting Rights That History Almost Forgot.” NextShark, November 6, 2019. Accessed November 18, 2019. https://nextshark.com/mabel-lee-womens-suffrage-pioneer/.

Snay, Mitchell. Horace Greeley and the Politics of Reform in Nineteenth-Century America. Lanham, MD: Rowman \& Littlefield, 2011.

Steffes, Tracy. “Chinese.” Encyclopedia of Chicago. Accessed November 26, 2019. http://www.encyclopedia.chicagohistory.org/pages/285.html.

Soennichsen, John. 2012. “The Chinese Exclusion Act of 1882.” Pacific Northwesterner 56 (2): 1-29. Accessed November 18, 2019. https://search-ebscohostcom.login.ezproxy.library.ualberta.ca/login.aspx?direct $=$ true \&db=31h\&AN=83242017\& site $=$ ehost-live\&scope $=$ site.

“The Boxer Indemnity Scholarship Program.” China Comes To MIT. Accessed November 26, 2019. http://chinacomestomit.org/new-page-2.

Tseng, Timothy. “Asian American Legacy: Dr. Mabel Lee.” Tim Tseng, December 12, 2013. Accessed November 18, 2019. https://timtseng.net/2013/12/12/asian-american-legacy-drmabel-lee/.

Xiao, Yue. “Chinese economic development and Chinese women economists," in The Routledge Handbook of the History of Women's Economic Thought ed. Kirsten Madden and Robert W. Dimand. 290-306. Abingdon: Routledge, 28 Sep 2018. Accessed Nov 18, 2019.

Yamashita, Kiyomi. "A Comparative Study of Chinatowns around the World: Focusing on the Increase in New Chinese Immigrants and Formation of New Chinatowns.” Japanese Journal of Human Geography 65, no. 6 (2013): 527-44. https://doi.org/10.4200/jjhg.65.6_527. 